\title{
Functional Analysis of Telajakan Plants and Space in Northern Denpasar, Bali, Indonesia
}

\author{
Sadahisa Kato' ${ }^{1}$, Kosuke Hishiyama ${ }^{2}$, Anak Agung Ketut Darmadi ${ }^{3}$, \\ Ngakan Ketut Acwin Dwijendra ${ }^{4}$, Dewa Ngurah Suprapta ${ }^{5}$ \\ ${ }^{1}$ Institute of Global Human Resource Development, Okayama University, Okayama, Japan \\ ${ }^{2}$ Faculty of Applied Sociology, Kindai University, Higashiōsaka, Japan \\ ${ }^{3}$ Faculty of Mathematics and Natural Sciences, University of Udayana, Jimbaran, Badung, Bali, Indonesia \\ ${ }^{4}$ Faculty of Engineering, University of Udayana, Jimbaran, Badung, Bali, Indonesia \\ ${ }^{5}$ Faculty of Agriculture, University of Udayana, Jl. PB. Sudirman, Denpasar, Bali, Indonesia \\ Email: skato1314@gmail.com
}

How to cite this paper: Kato, S., Hishiyama, K., Darmadi, A.A.K., Dwijendra, N.K.A. and Suprapta, D.N. (2019) Functional Analysis of Telajakan Plants and Space in Northern Denpasar, Bali, Indonesia. Open Journal of Ecology, 9, 15-24.

https://doi.org/10.4236/oje.2019.92002

Received: December 28, 2018

Accepted: February 17, 2019

Published: February 20, 2019

Copyright (c) 2019 by author(s) and Scientific Research Publishing Inc. This work is licensed under the Creative Commons Attribution International License (CC BY 4.0).

http://creativecommons.org/licenses/by/4.0/ Open Access

\begin{abstract}
Bali Island, Indonesia, is undergoing rapid land use changes owing to tourism-related development and urbanization. Consequently, urban green spaces, which provide a myriad of benefits to residents, are disappearing and deteriorating. Focusing on telajakan, a strip of traditional green space between the frontal wall of a housing compound and a ditch/pedestrian path in a roadside, the study aims: 1) to investigate and document the changes that are occurring with regards to telajakan in Denpasar, Bali and 2) to evaluate the functions of the plantings in telajakan. The research methods include literature review on traditional green spaces in Bali, vegetation survey at a lot scale, and homeowner interviews with the help of local experts. The study found that: 1) aesthetics, economics, and rituals are the top three functions provided by the telajakan plants with aesthetic function being by far the most provided function; 2) species diversity does not correspond with functional diversity; and 3) telajakan space itself is often minimized or sometimes lost completely for more inner, privatized space or for vehicle parking lot for shop owners. Since telajakan is an important component of traditional Balinese architecture, its loss, degradation, and marginalization necessarily lead to the loss of Balinese culture and identity. This study hints, however, a new form of social interaction through aesthetically-pleasing telajakan. Also, functional diversity, which is arguably as important as species diversity, can be maintained by carefully selecting indigenous species with multiple functions.
\end{abstract}

\section{Keywords}

Telajakan, Bali, Urban Green Spaces 


\section{Introduction}

Urban green spaces provide many benefits to residents such as beautification, air and water pollutant removal, buffer to noise, shade, and remediation to the urban heat island effect. In the island of Bali, Indonesia, there are two types of traditional green spaces called natah and telajakan by the locals [1]. We have focused on telajakan, traditional green spaces in the southern urban areas in Bali, Indonesia. Telajakan is located between the frontal wall of a housing compound and a ditch/pedestrian path in a roadside. The width of telajakan is determined by Balinese traditional architecture, which cases between 1.0 and 2.2 meters, and by Bali Regulation No. 10/1999, which cases between 0.5 and 2.0 meters [1], [2]. In the past, the planted species in telajakan were used mostly for ritual purposes. The plantings provided plant and flower materials for Balinese daily rituals (offering to the gods).

Recently telajakan is being lost under rapid urbanization, and the plantings in telajakan are changing in terms of their functions, types, and dimensions. However, since telajakan has always been an element of traditional southern Balinese architecture, local people pay little attention to the changes that are occurring and few scientific studies have been conducted on telajakan. Therefore, the objectives of this study are: 1) to investigate and document the changes that are occurring with regards to telajakan in Denpasar, Bali and 2) to evaluate the functions of telajakan plants.

\section{Preceding Studies}

To our knowledge, almost no ecological analysis of telajakan exists; very little data on the plantings in telajakan is available or has been published in English. There are, however, some preceding studies on urban green spaces in Bali. Cultural and historical studies of telajakan do exist, including Yudantini (2012) whom argues that telajakan has helped form the identity of the Balinese on the traditional village landscape in Bali [1]. Telajakan also has spiritual meaning for the Balinese to protect homeowners from invisible dangers [2]. Putra et al. (2013) illustrate the transformation of the traditional Balinese house for tourist facilities, and documented the process of marketization and re-embedding of the traditional elements adjusted for the modern context [3]. Brata (2014) examined the process of commodification of telajakan in Ubud Village, concluding that the telajakan's value as traditional green open space is neglected, resulting in ecological damage and the extinction of the aesthetics of the Balinese architecture, and witnessing the destruction of the Balinese identity [4].

With regards to the functions of telajakan, literature review shows that the primary functions of traditional plants in telajakan are religious and economic. The plants are used for religious ceremonies, medicinal purposes, spice, aesthetics, and micro economy [5]. Telajakan provides a space to place the penjor during traditional ceremonies [1]. The purposes of telajakan space are aesthetic, safety, social and spiritual-for example, greening, widening the view distance, 
keeping and defending the building boundary for safety and building comfort, and providing intimacy and identify of neighborhoods [1]. Although every telajakan is owned, provided, and maintained by the household, its use is characterized by semi-public nature [2]. Telajakan used to provide a place for communication with neighbors, and used to be a place for street vendors and wagon stops [2]. However, a frontal wall as well as telajakan is being lost as owners transform the space, accommodating tourism and changing lifestyles [1], [6].

\section{Methods}

Bantas village (see Figure 1 for location) in northern Denpasar was chosen after the consultation with Dr. Ngakan Ketut Acwin Dwijendra of University of Udayana, an expert of telajakan from the viewpoint of traditional Balinese architecture [2]. Also, earlier research found that Bantas village is a frequent winner of the citywide telajakan competition (see [7]).

In the village, the authors observed the telajakan, took photos, and interviewed the owner who operates a convenience shop on the 31st of August, 2017. Six telajakan samples were chosen among the houses that face the main street (Figure 2). To determine a general trend, every other house on both sides of the street was selected. At each telajakan, vegetation survey was conducted and the width of the telajakan was measured. Using Keng (1978) and Periplus Editions (1999) as references, all the plantings in each telajakan were identified and their functions were determined [8], [9]. The functions provided by the plantings include aesthetic, economic, ritual, shade, medicinal, protection from intrusion, anti-mosquito, biofungicide, and crops. Also, for each species, its number was counted. When too many individual species were present like a ground cover, experts estimated the number of individuals by counting the number of individuals in a limited area and multiplying the number by the area.

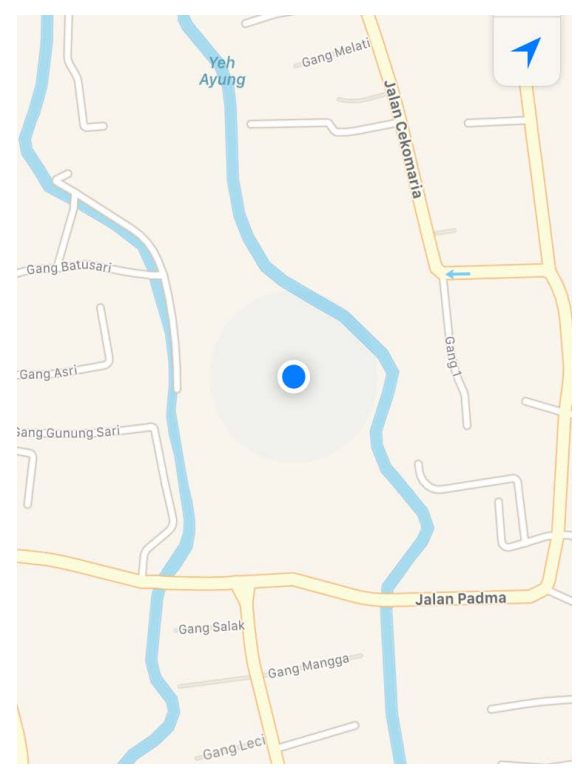

Figure 1. Location of Banjar Bantas (Apple Maps). 


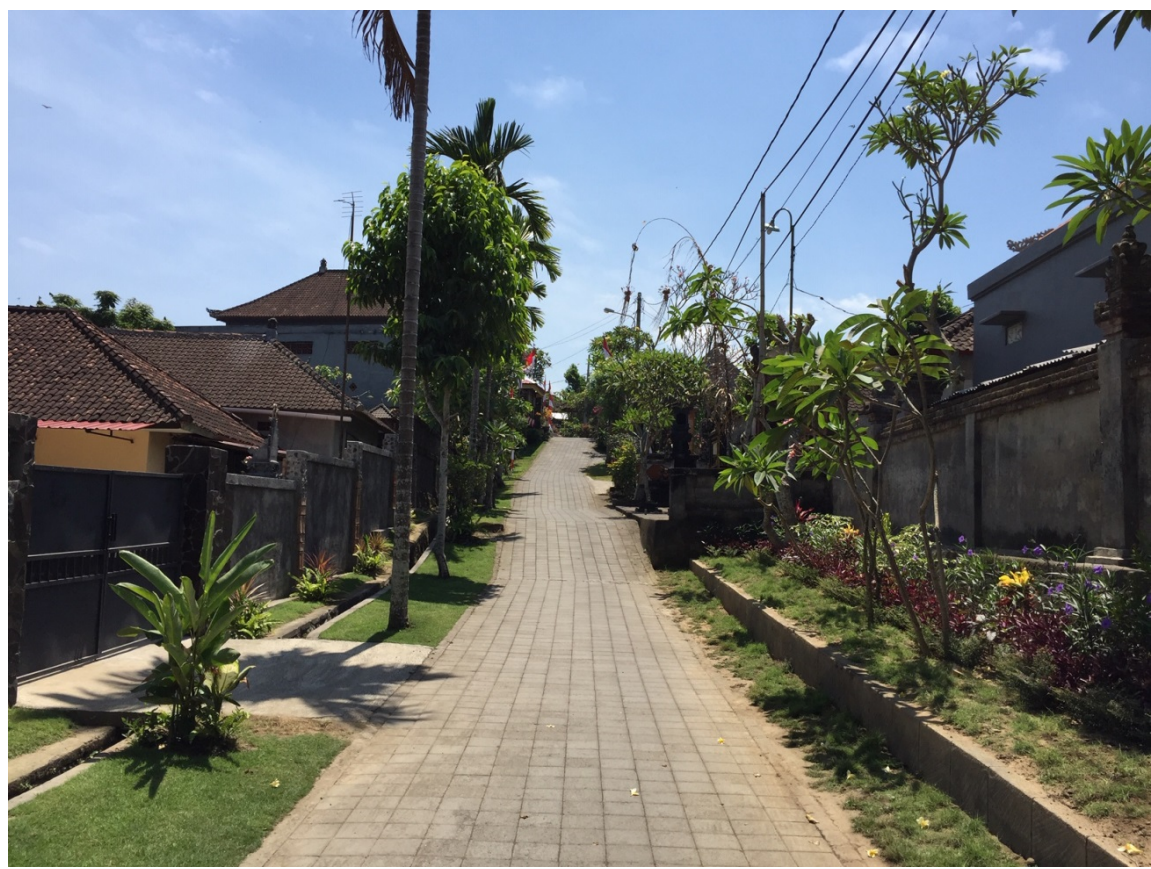

Figure 2. View of the main street from the south.

The data of each telajakan were tabulated into a table with a scientific name of each species, the number of individuals, and the functions provided by the plantings. Based on the table, two types of figures were created. Both types of figures show that for each function how much of the species present provides the particular function. The difference is that Figures 3-8 take the number of individuals into account. For example, if the percentage is $80,80 \%$ of all the plants in Sample X, considering the number of individuals, provide the particular function such as the aesthetic function.

\section{Results}

For all six samples, aesthetics, economics, and rituals are the three most important functions which the planted vegetation has (Figures 3-8). Aesthetic function is by far the most provided function by the planted species with $93.6 \%$ on average, followed by economic function with $55.9 \%$. In terms of the percentage of functions provided by the plants, Samples $1-3$ and 5 have a similar trend; Samples 4 and 6 have the same trend.

Examining each sample in order, Samples 1 and 2 have the same trend (Figure 3 and Figure 4). Aesthetic function is provided by most of the plants, followed closely by economic function. Far behind third is ritual function. For Sample 3 (Figure 5), the order is the same (aesthetics first, economics second, and rituals third) but the difference between aesthetics and economics is larger and the difference between economics and rituals is smaller than Samples 1 and 2. For Sample 4 (Figure 6), the result is very different from Samples 1 - 3 due to three abundant species with only aesthetic function: Cuphea hyssopifolia, Alternanthera ficoidea, and Ruellia malacosperma. Both economic and ritual 


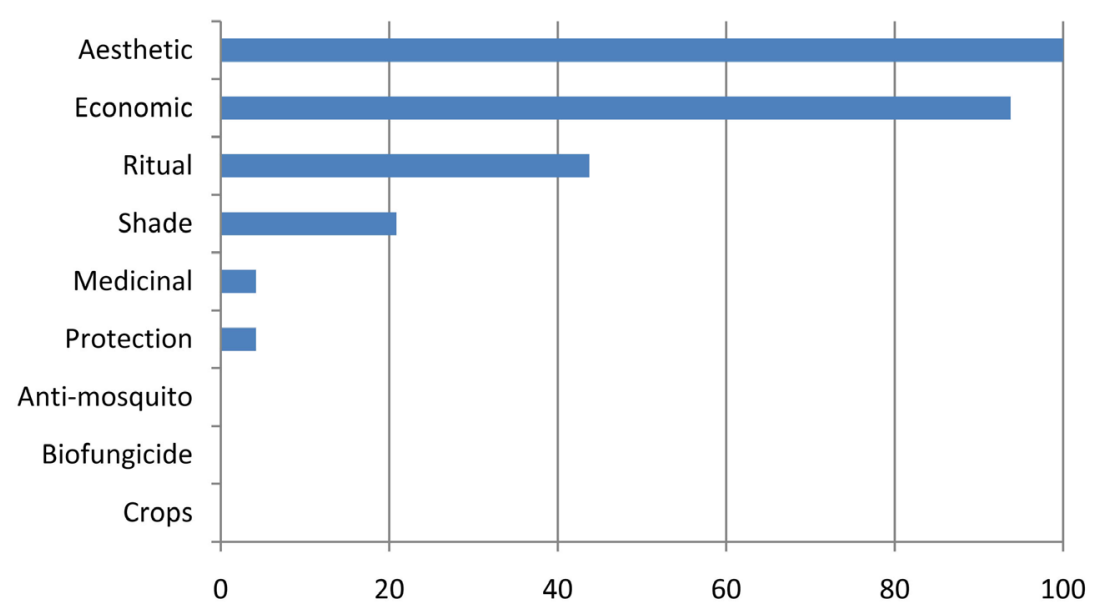

Figure 3. Percentage of functions provided by the plants considering the number of individuals in Sample 1.

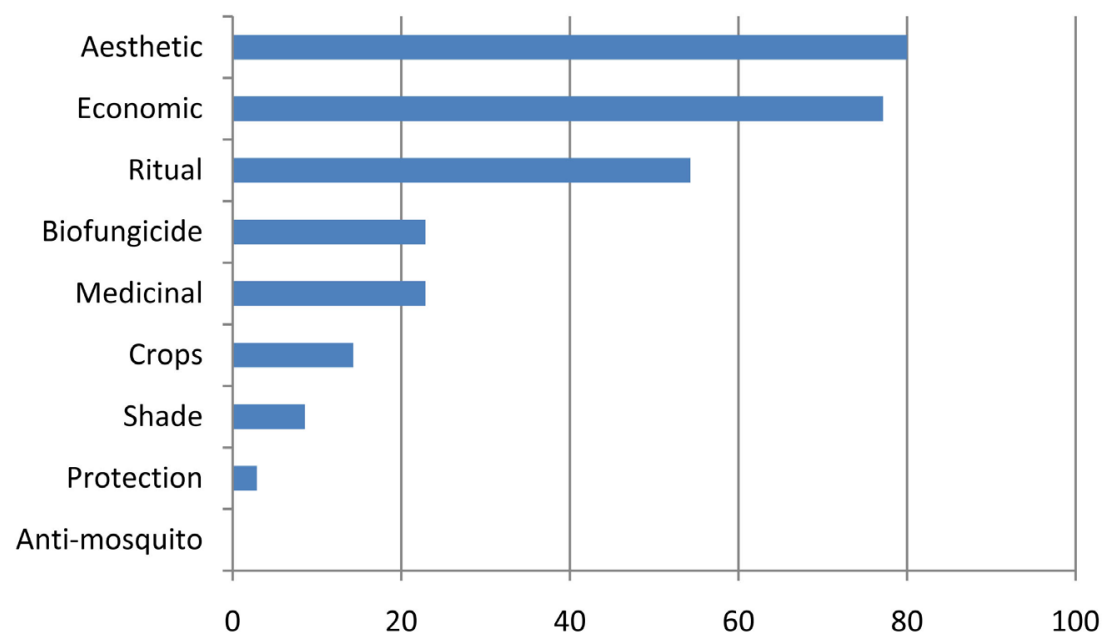

Figure 4. Percentage of functions provided by the plants considering the number of individuals in Sample 2.

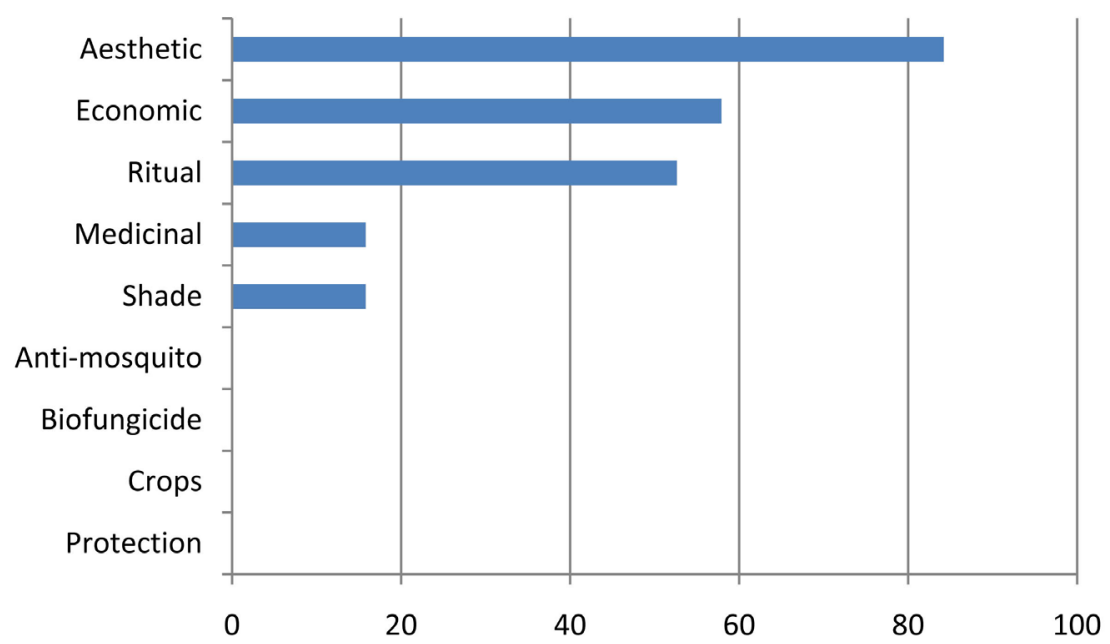

Figure 5. Percentage of functions provided by the plants considering the number of individuals in Sample 3. 


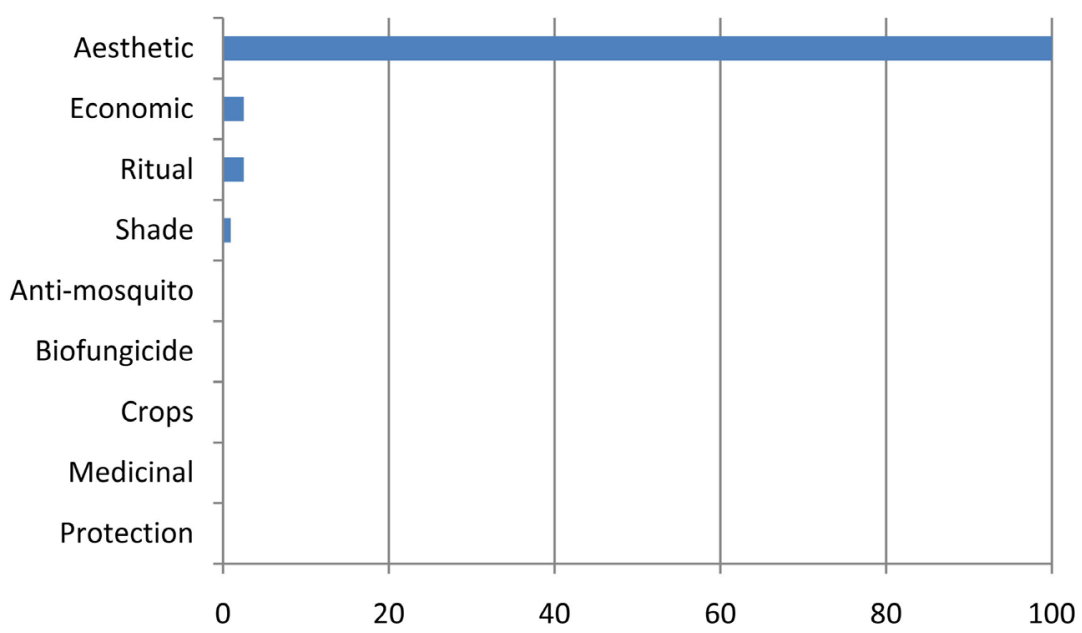

Figure 6. Percentage of functions provided by the plants considering the number of individuals in Sample 4.

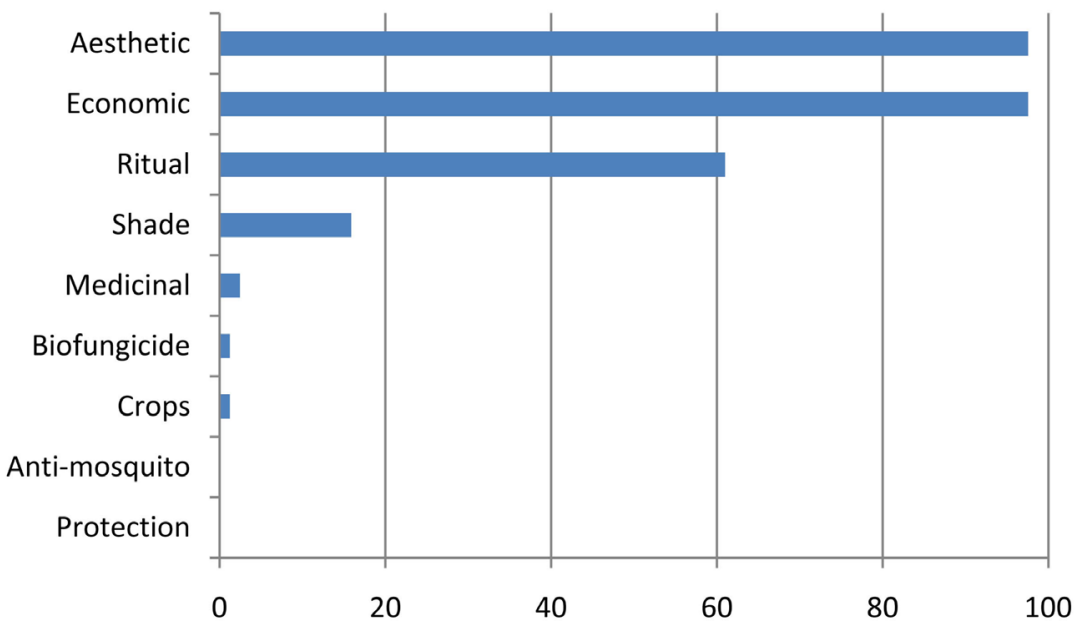

Figure 7. Percentage of functions provided by the plants considering the number of individuals in Sample 5.

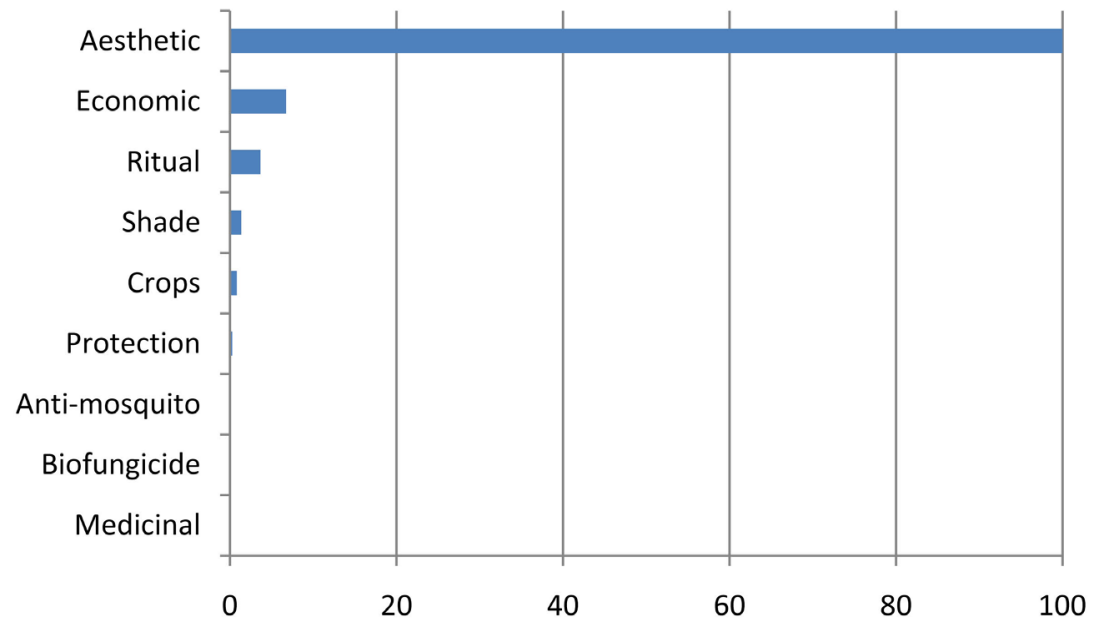

Figure 8. Percentage of functions provided by the plants considering the number of individuals in Sample 6. 
functions have very small share (2.5\%). Sample 5 (Figure 7 ) is very similar to Sample 1. Aesthetics and economics have the same percentage of 97.6\%; ritual function is the third most common function with $61 \%$. Finally, Sample 6 has exactly the same trend as Sample 4. Aesthetic function is by far the most common function; actually $100 \%$ of the species planted provide this function. Economic and ritual functions are distant second and third, respectively. The sheer number of three species, the same three species as in Sample 4, with only aesthetic function has a very large effect on the appearance of the resulting graph (Figure 8).

The highest percentage of shade function is provided by the plants in Sample 1 with $20.8 \%$, followed by Sample 5. Examples of plants with shade function are Plumeria acumunata and Rhapis excelsa. The highest percentage of medicinal function is provided by the plants in Sample 2 with $22.9 \%$, followed by Sample 3. Examples of plants with medicinal function include Aloe vera and Erythrina variegata. Protection means protection from intrusion. For example, Opuntia spp. are plants with protection function.

In terms of total number of different species, Sample 6 has the most number of species (most species diverse). 19 species are identified in Sample 6, followed by 13 species in Sample 5, and 12 species in Sample 1 (Table 1). The top three and its order remains the same, considering the number of cultivars. As for the width of telajakan, Sample 3 is the narrowest with $159 \mathrm{~cm}$; Sample 1 is the widest with $470 \mathrm{~cm}$ (Table 1). Though the sample size is small, there is no apparent relationship between the species diversity and telajakan width.

\section{Discussion}

Reflected on the number of each species including cultivars on the analysis, the kind of plant functions favored by the local residents (i.e., owners) was clearly revealed. Based on the result of vegetation survey, we can conclude that aesthetics, economics, and rituals are the three most favored functions by the telajakan (home) owners. Among the three functions, aesthetic function is by far the most popular function. This is evident in the planting of species with only aesthetic function such as Cuphea hyssopifolia, Alternanthera ficoidea, and Ruellia malacosperma-plants with colorful flowers and leaves. Also, some gardens are well maintained with trimmed branches and leaves (Figure 9).

Previous study [7] found a similar trend in terms of the plant functions favored in another village in northern Denpasar with bonsai trees and manicured vegetation with grounds being swept well. Kato et al. (2017) pointed out that

Table 1. The number of species in each sample and telajakan width.

\begin{tabular}{ccccccc}
\hline & Sample 1 & Sample 2 & Sample 3 & Sample 4 & Sample 5 & Sample 6 \\
\hline $\begin{array}{c}\text { Num of species } \\
\text { Num of species }\end{array}$ & 12 & 10 & 7 & 10 & 13 & 19 \\
$\begin{array}{c}\text { including cultivars } \\
\text { Telajakan width (cm) }\end{array}$ & 16 & 11 & 9 & 11 & 18 & 23 \\
\hline
\end{tabular}




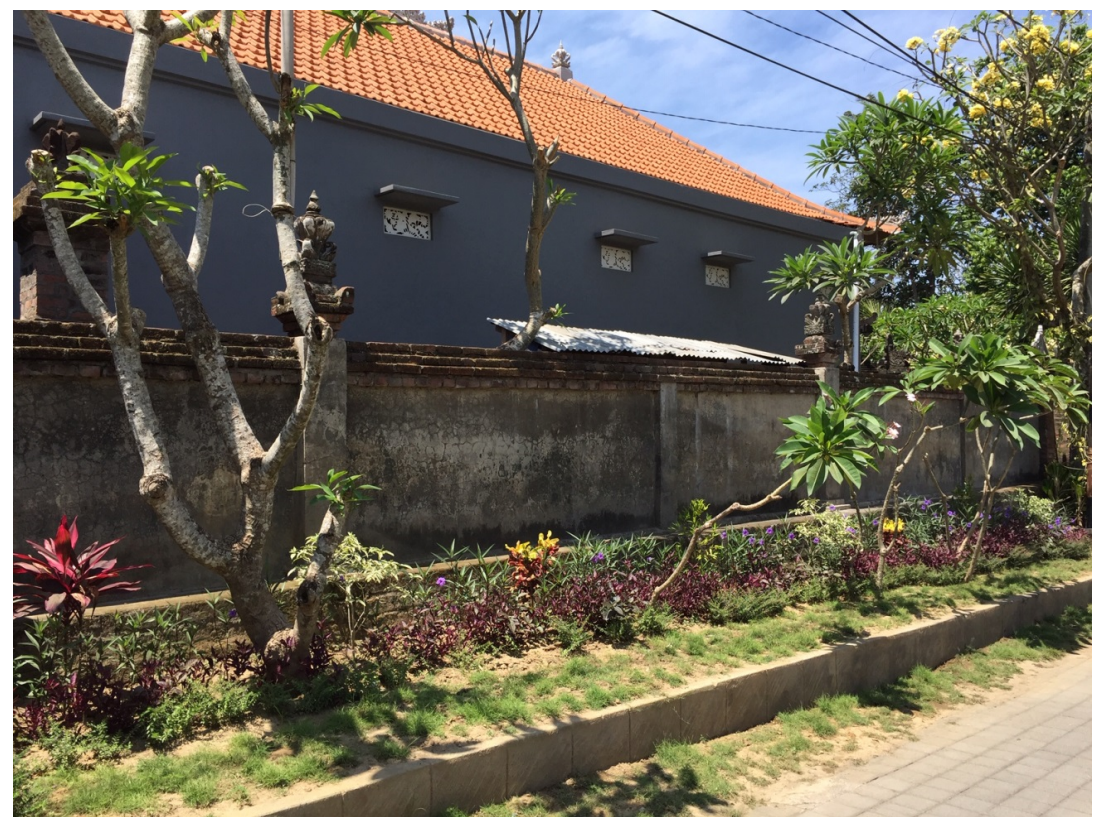

Figure 9. Aesthetically-pleasing telajakan.

manicured telajakan with plants with colorful flowers and leaves, lolly-pop trees, and exotic species has become a status symbol of the owner, giving new meaning to telajakan [7]. The fact that both villages are regular winners of the telajakan competition (public hygiene and removal of mosquito habitats) underscores the importance of aesthetics to the scenery of the street. The popularity of aesthetic function in Br. Bantas corroborates the findings of the earlier study.

Although Figure 6 of Sample 4 and Figure 8 of Sample 6 may appear rather peculiar, considering the number of individuals, these graphs represent well the actual appearance of telajakan and the occupancy of each function. Comparing the two figures (Figure 8 and Figure 10) of Sample 6, both rightly express the percentage of functions provided by the plants in Sample 6. The difference is that Figure 8 takes the number of individuals of each species into account whereas, Figure 10 does not. Doing so gives the graph individual number-weighted percentage of functions, a "feel" close to the field observation. The reasoning behind this representation such as Figure 8 is that if an owner values a particular function, s/he would plant more of these species.

In terms of the number of functions provided by the plants, Sample 2 is the most diverse with eight functions, followed by Sample 5 with seven functions. This result does not correspond with the number of species present (i.e., species diversity). Therefore, in terms of managing for functional diversity, it is inferred that even when an owner cannot afford to plant many different species, s/he can diversify the number of functions provided by the plants by carefully selecting those species with multiple functions such as Plumeria acumunata, Aloe vera, and Azadirachta indica.

Traditionally telajakan has multiple functions such as provision of plant and flower materials for Balinese daily rituals, greening and building comfort, and 


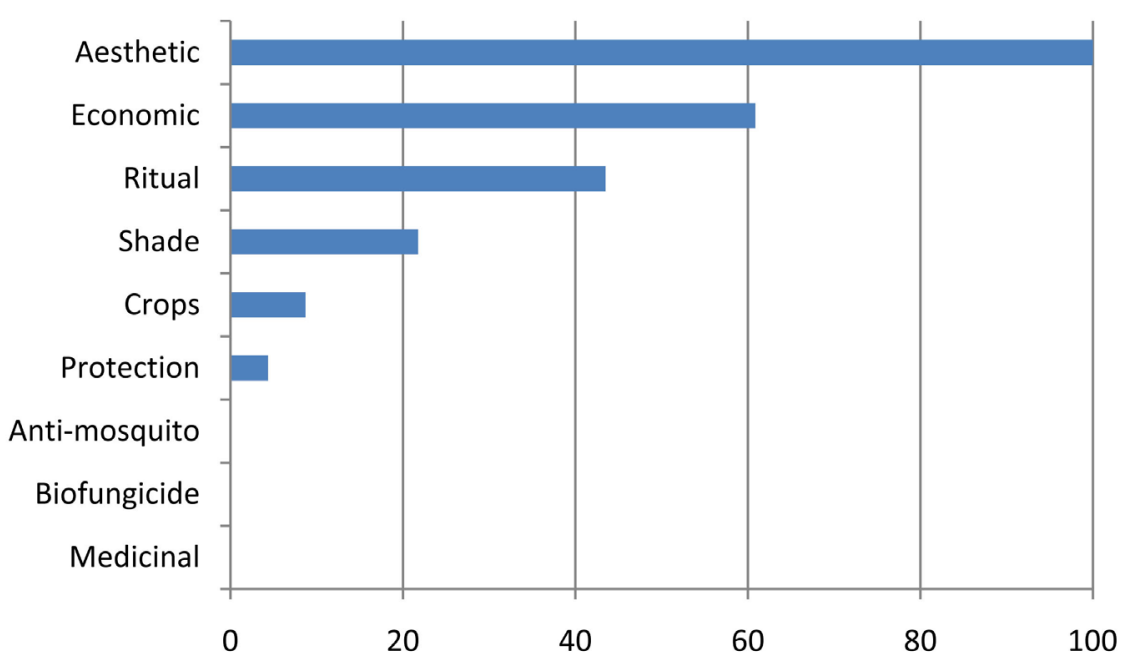

Figure 10. Percentage of functions provided by the plants without considering the number of individuals in Sample 6.

offering semi-public space for street vendors and neighbors. However, the results show that only a couple of functions is strongly favored, focusing on aesthetic and economic aspects. Although ritual function is the third most common function provided by the planted species, the importance of this function seems to be taken over by aesthetics, for people buy an offering set from a store for daily rituals and do not harvest leaves and flowers daily, as they used to do, at least in the city. For bigger Hindu festivals, some people still use their own plants to prepare offerings. Anecdotally, we heard a story that neighbors ask an owner for permission to pick some flowers for daily offerings or bigger village festivals-note, public use of telajakan plants that are privately owned and maintained.This is when conversation between the owner and the neighbor is born. Also, when an owner has a traditional telajakan with beautiful flowers, neighbors sometimes take pictures to post to Instagram. This kind of use of telajakan may hint a new, modern social interaction via telajakan.

Finally, although the results are based on a fairly representative telajakan survey as described in the methods section, the samples were not chosen randomly and the number of samples is small. To draw a more comprehensive conclusion, it is necessary to collect more evidence by expanding the locations where telajakan is surveyed, such as including the villages in other parts of Denpasar and of different socioeconomic status, and by evaluating the plant data as well as socioeconomic data.

\section{Conclusion}

Although literature review shows that telajakan is an important element in the traditional village landscape in Bali, urbanization and privatization threaten the existence of telajakan and change its species composition. Now there are fewer telajakan plants with religious function and more species with aesthetic function-many of them being exotic ornamental plants. This study suggests, how- 
ever, that functional diversity can be maintained by carefully selecting indigenous species with multiple functions. New form of social interaction is also born via aesthetically-pleasing telajakan through neighbors and passers-by taking photos of telajakan and posting them to social networking service.

\section{Acknowledgements}

The authors would like to thank anonymous reviewers for their comments, which helped to greatly improve the paper. This research is funded by the Housing Research Foundation JUSOKEN. The authors are grateful for its support.

\section{Conflicts of Interest}

The authors declare no conflicts of interest regarding the publication of this paper.

\section{References}

[1] Yudantini, N.M. (2012) Natah and Telajakan: The Role and Identity in Indigenous Villages. Proceedings of International Seminar on Place Making and Identity 2012, Jakarta, 26-27 September 2012, 179-187.

[2] Dwijendra, N.K.A (2008) Arsitektur Rumah Tradisional Bali. Kerjasama Bali Media Adhikarsa [dengan]. Udayana University Press, Denpasar.

[3] Putra, D.G.A.D., Lozanovska, M. and Fuller, R. (2013) The Transformation of the Traditional Balinese House for tourist Facilities: Managing a Home-Based Enterprise and Maintaining an Architectural Identity. Proceedings of the 2013 Asia-Pacific Management and Business Application International Conference on Management and Business Science, Universitas Udayana, Denpasar, Bali, 53-67.

[4] Brata, I.B. (2014) Commodification of Telajakan at Ubud Village, Gianyar, Bali. E-Journal of Cultural Studies, 7, 1-6. http://ojs.unud.ac.id/index.php/ecs/article/view/8417

[5] Yudantini, N.M. and Jones, D. (2015) The Role of Traditional Regulation in the Indigenous Villages for Conservation of Village Pattern. Proceedings of 21 st International Sustainable Development Research Society Conference, International Sustainable Development Research Society, Geelong, Vic., 1-10.

[6] Putra, I D.G.A.D. Diasana, Lozanovska, M. and Fuller, R. (2017) A Methodology to Evaluate the Transformation of Traditional Balinese Houses as a Consequence of Tourism. International Journal of Architectural Research, Universitas Udayana, 11, 83-100.

[7] Kato, S., Hishiyama, K., Darmadi, A.A.K. and Suprapta, D.N. (2017) Changing Roles of Traditional Small Urban Green Spaces (Telajakan) in Bali, Indonesia. Open Journal of Ecology, 7, 1-11. https://doi.org/10.4236/oje.2017.71001

[8] Keng, H. (1978) Orders and Families of Malayan Seed Plants. Singapore University Press, Singapore.

[9] Periplus Editions (1999) 500 Popular Tropical Plants. Periplus Editions (HK) Ltd., Hong Kong. 